\title{
СМИСЛОВІ ВИМІРИ МУЗИЧНОЇ ОБРОБКИ ЯК МИСТЕЦЬКОГО ЯВИЩА І СФЕРИ КОМПОЗИТОРСЬКОЇ ІНТЕРПРЕТАЦЇ̈
}

\author{
Коновалова І. Ю.
}

\section{ВСТУП}

У дискурсі сучасної культурології та мистецтвознавства загострюється потреба в осягненні сутнісних для художньої практики процесів і явищ, які набувають нового естетичного змісту і модернізації за умов глибинних трансформацій та парадигмальних змін, притаманних постмодерній епосі.

Накопичення величезного масиву музично-художньої інформації, усвідомлення поліфонічності світовідчуття і культури на початку XXI ст. формують відкритий смисловий простір для нескінчених тлумачень $\mathrm{i}$ породження унікальних художньо-комунікативних стратегій. Означена ситуація сприяє зростанню інтеграційних мистецьких процесів та діалогічної скерованості композиторської свідомості, посиленню інтерпретаційних проявів в музиці та тенденцій інтертекстуальності. Однією $з$ характерних ознак сучасної композиторської практики стає тяжіння до філософського концептуалізму, а також ретроспективна занурюваність й орієнтація творців на осягнення набутого інтелектуального й мистецького досвіду.

Джерела звернення до традицій і образів культури попередніх епох, фольклорного та культового мелосу (обраних за інтонаційну основу авторських творів), а також опора на усталені жанрово-стильові моделі в їх оригінальній композиторській інтерпретації $\epsilon$ відбиттям діалогу творців музики з різними світовідчуваннями та проявом характерного для культури сьогодення історизму мислення.

Переосмислення духовної спадщини і художніх надбань минулого в дихотомічних аспектах «своє - чуже», «традиційне - новітнє» значною мірою зумовлюють новаторство композиторів, своєрідність їхнього авторського стилю, ініціюють пошуки нових технологій та індивідуальних креативних позицій, а також сприяють посиленню процесів культурологізації творчості. На цій підставі актуалізується звернення до проблематики обробки в музичній царині, що $є$ принципово важливою в концептосфері феноменології музичної творчості й авторології, зокрема музичного авторства ${ }^{1}$, а також діалогістики та художньої інтерпретації.

\footnotetext{
${ }^{1}$ Коновалова I. Феномен композитора в часопросторі європейської музичної культури XX століття: модуси теоретичного осягнення : монографія. Харків : ТОВ «Планета-Принт», 2018. С. 105. 
Широта функціювання обробки в музиці (музична обробка) та набутий художній досвід у цій царині, сфокусований в інструментальній та вокальній творчості, зумовлюють незгасаючий науково-дослідницький інтерес до даного явища і різнобічні аспекти його осмислення. Питання жанрового буття музичної обробки та методів опрацювання першоджерел, фольклорних і культових, в авторській творчості порушуються в теоретичних розвідках М. Давидова ${ }^{2}$, В. Дейнеги ${ }^{3}$, О. Демченка ${ }^{4}$, Ю. Свдокимової ін. Формуванню системних уявлень про творчу сферу музичної обробки сприяли наукові праці В. Глівінського ${ }^{10}$, В. Дейнеги ${ }^{11}$, О. Жаркова ${ }^{12}$, Ф. Ліпс ${ }^{13}$, Р. Мікенайте ${ }^{14}$, у яких виявляються зв'язки останньої із проблемами еволюції музичного мислення та певних композиторських стилів, пропонується систематизація жанрів у системі «художнього перекладу» (за О. Жарковим), серед яких транскрипція, перекладення, аранжування тощо, та визначається вищий творчий статус обробки в порівнянні зі згаданими різновидами.

Плідними у виявленні специфіки обробки стали сучасні дослідження у сфері теорії жанру транскрипції, презентовані працями Н. Прокіної ${ }^{15}$, М. Борисенко ${ }^{16}$, В. Руденка ${ }^{17}$, Л. Когана ${ }^{18}$, М. Голомб ${ }^{19}$, Л. Годовського ${ }^{20}$.

\footnotetext{
${ }^{2}$ Давидов М. Про музично-естетичний зміст творчого процесу перекладання музичних творів для баяна. Українське музикознавство. Київ, 1974. Вип. 10. С. 200-207.

3 Дейнега В. Оркестровка як різновид інтерпретації. Науковий вісник Наиіональної музичної академії ім. П.І. Чайковського : збірник статей. Київ : НМАУ, 2001. Вип. 18. С. 133-142.

${ }^{4}$ Демченко А. Жанр фольклорной обработки в музыкальном искусстве России начала XX века. Развитие народных традищий в музыкальном исполнительстве, творчестве и педагогике: опыт коллективного исследования : межвузовский сборник научных трудов / ред.-сост. Д. Варламов. Екатеринбург : Уралтрейд, 2000. С. 35-41.

${ }_{5}^{5}$ Евдокимова Ю. Органные хоральные обработки Баха. Русская книга о Бахе : сборник статей / сост. Т. Ливанова, В. Протопопов. Москва : Музыка, 1985. С. 221-247.

${ }^{6}$ Иванова Л. Жанр фольклорной обработки в русской музыке XX века. Развитие народныхх традищий в музыкальном исполнительстве, творчестве и педагогике : опыт коллективного исследования : межвузовский сборник научных трудов / ред.-сост. Д. Варламов. Екатеринбург : Уралтрейд, 2001. С. 66-71.

Рязанова Н. Органные хоральные обработки И.С. Баха (их композиционно-структурные особенности) : автореф. дис. ... канд. искусств. Ленинград : ЛГК, 1979. 20 с.

${ }^{8}$ Матусевич Н. Гармонічне варіювання в обробках українських народних пісень М. Лисенка. Украӥнське музикознавство : збірник наукових праць. Київ, 1957. Вип. 2. С. 81-90.

${ }^{9}$ Фільц Б. Хорові обробки українських пісень. Київ : Музична Україна, 1965. 133 с.

${ }^{10}$ Гливинский В. Жанр обработки в позднем творчестве И. Стравинского. Позднее творчество И.Ф. Стравинского : исследование. Донецк : Донеччина, 1995. С. 159-175.

$1 \mathrm{Дейнега} \mathrm{В.} \mathrm{Оркестровка} \mathrm{як} \mathrm{різновид} \mathrm{інтерпретації.} \mathrm{Науковий} \mathrm{вісник} \mathrm{Національної} \mathrm{музичної}$ академії ім. П.І. Чайковського : збірник статей. Київ : НМАУ, 2001. Вип. 18. С. 133-142.

12 Жарков О. Художній переклад в музиці: проблеми і рішення : автореф. дис ... канд. мистецтв. Київ : КДК, 1994. 27 с.

${ }^{13}$ Липс Ф. О переложениях и транскрипциях. Баян и баянисты. Москва : Советский композитор, 1977. Вып. 3. С. $86-108$.

14 Микенайте Р. Особенности гармонического языка обработок литовских народных песен. Boпросы теории музыки. Москва : Музыка, 1975. Вып. 3. С. 213-236.

55 Прокина Н. Фортепианная транскрипция. Проблемы теории и истории жанра : автореф. дис. ... канд. искусств. Москва : МГК, 1988. 21 с.

${ }_{16}^{16}$ Борисенко М. Жанр транскрипції в системі індивідуального композиторського стилю : автореф.

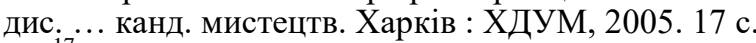

7 Руденко В. Концертная скрипичная транскрипция XX века и проблемы интерпретации. Музыкальное исполнительство : сборник статей / сост. и ред. В. Григорьева, В. Натансона. Москва : Музыка, 1979. Вып.10. С. 22-56.
} 
Важливими для обгрунтування музичної обробки $\epsilon$ визначені особливості жанру транскрипції, що вбачаються: у переінтонуванні образного змісту твору-першоджерела в нових тембрових умовах (В. Руденко); у єднанні первинного та вторинного стилів (Н. Прокіна); у прояві дії інтерпретації (М. Борисенко).

Музикознавчий досвід вивчення заявленої проблематики, концептуальні засади теорії художньої (музичної) інтерпретації, царини «художнього перекладу» у музиці $\epsilon$ підгрунтям для обгрунтування широти іiї проявів музичної обробки в композиторській творчості.

Семантична значущість музичної обробки в культурному часопросторі, підвищення іiі мистецького статусу і ролі у процесах культуротворення у зв'язку з посиленням інтерпретативної компоненти у структурі сучасного художнього мислення й оновленням методів опрацювання музичної інформації (поширених навіть на сферу звуку як первинного матеріалу музики, iї «молекулярної» інтонаційно-смислової структури) зумовлюють необхідність спеціального мистецтвознавчого розгляду.

Мета пропонованого дослідження - окреслити смисловий простір явища музичної обробки, розкрити його креативні властивості як різновиду художньої інтерпретації та форми композиторської авторепрезентації.

\section{1. Рецепції поняття «обробка» у сучасному науковому дискурсі}

Центральне для пропонованого дослідження поняття - «обробка» - $\epsilon$ міждисциплінарним та полісемантичним. Генеза цього найпоширенішого поняття пов'язана 3 дієсловом «робити», у семантиці якого пердусім акцентується процес або факт здійснення будь-яких зусиль - фізичних чи інтелектуальних, здатність «<..> за допомогою упорядкування, удосконалення надавати чому-небудь викінченого вигляду», а також «певними діями, операціями $<\ldots>$ доводити до певного стану» ${ }^{21}$, зокрема «піддати виділці, змінам, аналізу, зробити готовим для будь-чого <...> обробити шкіру, землю, рану, інформацію» ${ }^{22}$.

Серед численних тлумачень терміна «обробка», наданих у словникових джерелах, увагу привертає багатозначність його розумінь та підкреслення трьох принципово важливих аспектів: 1) дії за значенням обробляти; 2) результату дії за значенням обробляти;

\footnotetext{
18 Коган Г. Парадоксы об исполнительстве. O музыке: проблемы анализа. Москва : Советский композитор, 1974. С. 344-365.

19 Голомб М. Транскрипції музичних творів у ХIX ст. Спроба типології на прикладі творів Фрідеріка Шопена (переклад з польської М. Кушніра). Фридерік Шопен : збірник статей. Львів : Сполом, 2000. С. 201-222.

${ }^{20}$ Годовский Л. По поводу транскрипций, обработок и парафраз Транскрипции для фортепиано : в 2 руки. Песни Ф. Шуберта / сост. К. Сорокин. Москва : Музыка, 1970. Вып 1. С. 41-49.

${ }_{21}$ Словник української мови. Київ : Наукова думка, 1974. Т. 5. С. 569.

22 Ожегов С., Шведова Н. Толковый словарь русского языка : 80000 слов и фразеологических выражений. Российская академия наук. Институт русского языка им. В. Виноградова. Москва : Азбуковик, 1999. С. 435.
} 
3) видозмінення музичного твору (або фольклорного мелосу) шляхом гармонізації, аранжування або транскрипції ${ }^{23,24}$.

У процесі експлікації терміна «обробка» сутнісною $є$ акцентуація його креативно-дієвих властивостей і спрямованості на вдосконалення або оновлення обраного першоджерела 3 подальшою фіксацією результативності певних втручань. Принципово вагомим $є$ підкреслення у трактуванні сенсу обробки скерованості ії дій на об'єкт (обробка того, що існує) та змістовної конкретизації останніх (інформаційна, механічна, технічна, художня, музична, літературна обробка тощо).

Змістовно наближеним до поняття «обробка» в українській культурі $\epsilon$ термін «опрацювання» ${ }^{25}$. У семантиці даного терміна підкреслюється процесуальна скерованість та схильність до певної деталізації. Через концептуальну значущість поняття «обробка» у музичній культурі, узгодженість саме із цим ім'ям традиції жанру дослідницька увага концентрується навколо терміна і явища «обробка».

Етимологічну спорідненість із поняттям «обробка» виявляє термін «фактура» (від лат. facio - «роблю», «здійснюю», «формую»), що має такі значення: виготовлення, обробка, творення, твір.

Смислова множинність та функціювання в різних царинах людської діяльності - науці (фізика, геофізика, геохімія, металознавство й ін.), техніці, інформатиці, лінгвістиці, промисловому виробництві, а також літературній i художній, зокрема в музичній, сферах зумовили універсальність поняття «обробка» у культурі ${ }^{26}$.

У науковому дискурсі термін «обробка» трактують як засіб пізнання й інтерпретації текстів, інформаційних джерел, а також різноманітних матеріалів і документальних свідчень як вихідного знання. Обробці підлягають: результати експериментів, певні факти, графічні зображення, геофізичні сигнали (радіолокаційні й ін.). Терміном «обробка» позначають й окремі технологічні процеси і методи, спрямовані на будьяку практичну деформацію, видозміну матеріальних об'єктів під дією зовнішніх сил (тиск, точіння тощо) ${ }^{27}$.

Поширене ототожнення обробки з редагуванням, корегуванням фактів, явищ і підкреслення посередницької функції обробки (між початковим станом певного предмета та його кінцевим перетворенням). Типова також характеристика будь-яких (науково-технічні, статистичні) даних, відбита у стадіальному процесі: обробка - інтерпретація - систематизація ${ }^{28}$.

\footnotetext{
${ }^{23}$ Великий тлумачний словник сучасної української мови / уклад. і ред. В. Бусел. Київ ; Ірпінь : ВТФ Перун, 2001. С. 649.

${ }^{24}$ Словник үкраїнської мови : в 11-ти т. / АН УРСР. Інститут мовознавства ; за ред. І. Білодіда. Київ : Наукова думка, 1970-1980. Т. 5. 1974. С. 568.

${ }^{25}$ Там само. С. 727.

26 Коновалова I. Феноменологія музичної обробки (на матеріалі хорових творів українських композиторів XIX-XX ст.) : дис. ... канд. мистецтвозн.: 17.00.01. Харків, 2007. С. 12.

${ }^{27}$ Большой российский энциклопедический словарь. Москва : БРЭ, 2003. С. 1073.

${ }^{28}$ Обработка символьной информации : сборник статей / под ред. В. Серебрякова. Москва : ВЦ АН CCCP, 1986. $110 \mathrm{c}$.
} 
Вищезазначена універсальність поняття і явища «обробка» значною мірою зумовлена його безпосереднім зв'язком із багатовимірним поняттям «культура» (лат. cultura - «оброблення», «виховування», від cultivo «оброблюю», «впливаю») $)^{29}$, серед множинних трактувань якого одним із найважливіших $\epsilon$ «обробка». Згідно 3 етимологічним зв'язком понять «культура» й «обробка», сутність останньої вбачається у формуванні «вторинної природи» унаслідок здійснення певних культуротворчих дій щодо первинної даності та виявляється в діяльнісному, соціальному, ціннісно-змістовному та творчо-інтерпретаційному аспектах ${ }^{30}$.

У діяльнісному аспекті під обробкою розуміється здійснення цілеспрямованих інтелектуальних або фізичних операцій на основі застосування певних методів та інтерпретативних стратегій. Обробка як діяльність містить смислоутворюючі й аксіологічні аспекти та $\epsilon$ відкритою системою, що надає можливості тлумачення явищ і відкриття нових значень об'єктів, на які спрямована дія. Згідно із цим обробка $\epsilon$ формою інтерпретації певного досвіду, а також креативної активності, скерованої на вияв нових сенсів першоджерел, створення нової інформації та примноження механізмів і способів ії передачі.

Відкриття нових сенсів у процесі обробки першоджерела здійснюється в діалектиці традиційного - інноваційного та відбувається шляхом розуміння, тлумачення того, що вже існує, за збереження деяких первинних ознак. Виходячи з аксіологічного розуміння, обробка - це окультурена природа, «особливе оформлення природно-мовного середовища, самої людини (iї тіла, рухів, думок, почуттів, намірів, дій, відносин), що має ціннісний зміст» ${ }^{31}$. Властиві обробці відкритість, креативність та інші якості зумовлюють іiі здатність до ситуації культурного діалогу, що передбачає наявність суб'єкта й об'єкта, а також аспекти їх комунікації.

Різноманітним та різновекторним $є$ вживання поняття «обробка»у літературі і мистецтві (живопис, скульптура, музика й ін.). У загальному плані, обробка в художній сфері пов'язана із творчим переосмисленням і адаптацією традиційних тем і сюжетів (біблійні, міфологічні, історичні) мовою певного виду мистецтв. Іншим модусом буття обробки постає здійснення художньої реставрації, реконструкції та редакції, зокрема й авторедакції, текстів творів. Особливим виміром обробки, зокрема у виконавських видах мистецтва, $\epsilon$ відродження й модернізація твору (зокрема, вистави), створення його нової переосмисленої версії-редакції 3 набуттям сучасних рис.

\footnotetext{
${ }^{29}$ Культурология в вопросах и ответах / под ред. Г. Драча. Москва : Гардарики, 1999. С. 8.

30 Коновалова I. Феноменологія музичної обробки (на матеріалі хорових творів українських композиторів XIX-XX ст.) : дис. ... канд. мистецтвозн.: 17.00.01. Харків, 2007. С. 13.

${ }^{31}$ Гаврюшенко О., Шейко В., Тишевська Л. Історія культури : навчальний посібник. Київ : Кондор, 2004. C. 4. 
Художня обробка відіграє суттєву роль у процесі створення й редагування літературних текстів. М. Бахтін пов'язує форму та зміст художнього твору з особливістю засобів обробки матеріалу і вважає художній прийом важливим методом опрацювання певного змісту. Суттєвим є визначення цим автором літературної мови як обробленої мови, оскільки, на його думку, «митець за допомогою художнього слова обробляє світ» ${ }^{32}$.

У професійній авторсько-виконавській музичній творчості поняття «обробка» й «опрацювання» відносять до найзначніших. Розмаїття екзистенції обробки в музичному мистецтві детермінують різні тлумачення цього терміна.

На сучасному етапі зміст поняття «музична обробка» можна розкрити як у широкому, так і у вузько-конкретному значеннях. У широкому смислі «обробка в музиці (нім. Bearbeitung) - усяка видозміна нотного тексту музичного твору, яка має певну мету $<\ldots>\gg{ }^{33}$, зокрема пристосування для інших виконавців, використання в навчальнопедагогічній практиці або модернізацію твору. До провідних форм музичної обробки відносять перекладення, оркестровку, транскрипцію, кожна 3 яких має власну специфіку.

В іншому словниковому джерелі поняття «обробка» конкретизується як «видозміна музичного твору шляхом гармонізації, аранжування або транскрипції» ${ }^{34}$. Згідно із цим виданням, даний термін найчастіше вживається щодо гармонізації народних мелодій та їх адаптації для певних виконавських умов (у перекладі для вокального, хорового або інструментального складів). У більш вузькому значенні обробка вказує на практичне переосмислення та видозміну музичного тексту твору, його структурно-композиційних, жанрових і мовних параметрів.

У дослідницькій літературі утворилася традиція розглядати обробку як самостійний жанр у системі композиторської творчості, що має художню цінність, вирізняється вільним оригінальним підходом до обраного музичного тексту та є об'єктом авторського права ${ }^{35}$.

Суттєво важливим виявляється також дефініція поняття «обробка»у теорії музичної фактури, адже остання $\epsilon$ визначною у процесі музичної обробки.

Отже, найважливішими смисловими векторами дефініцій центрального для дослідження поняття, на наш погляд, $\epsilon: 1)$ тлумачення обробки як видозміни музичного тексту із широким діапазоном креативних можливостей вирішення останнього, закріплених у різних

\footnotetext{
${ }^{32}$ Бахтин М. Эстетика словесного творчества. Москва, 1979. С. 170-171.

${ }_{33}$ Музыкальная энциклопедия : в 6-ти т. Москва : Сов. энциклопедия, 1976. Т. 3. С. 1070

34 Музыкальный энциклопедический словарь / отв. ред. Г. Келдыш. Москва : Гос. научн. из-во «Большая советская энциклопедия», 1959. С. 185.

35 Самарин В. Хороведение и хоровая аранжировка : пособие для студентов высших учебных заведений. Москва : Академия, 2002. С. 189.
} 
жанрових формах (перекладення, транскрипція тощо); 2) усвідомлення культурного статусу обробки як об'єкта авторського права; 3) визнання обробки за рівнем творчої свободи вищім різновидом в ієрархії жанрових явищ «художнього перекладу» у музиці; 4) виокремлення як самостійної жанрової одиниці музичного мистецтва обробки фольклорного мелосу ${ }^{36}$.

Запропонований термінологічний аналіз поняття «обробка» окреслив множинність та багаторівневість інтерпретації останнього через його ототожнення з поняттям «культура». У понятті «обробка» фокусуються культуротворчі дії стосовно вихідного інтонаційного матеріалу, спрямовані на створення нового продукту («вторинної природи»), та визначаються результати такої дії. Широке тлумачення поняття «музична обробка» зумовлено амбівалентністю його функціювання на процесуально-діяльному (як метод), результативному (жанровий) та мовному (фактурний) рівнях ${ }^{37}$.

Розуміння ж специфіки музичної обробки потребує обгрунтування іiї інтерпретаційних властивостей.

\section{2. Художньо-інтерпретаційні детермінанти музичної обробки}

Осягнення концептуальних засад музичної обробки як царини композиторської авторепрезентації і сфери креативної діяльності, спрямованої на переосмислення інтонаційно-семантичних першоджерел (культурних текстів), детермінує висвітлення загальних проблем інтерпретації - художньої та музичної.

Інтерпретація (лат. interpretatio - «посередництво») - засіб тлумачення і форма когнації світу - використовується в усіх сферах людської життєдіяльності. У дискурсі філософської герменевтики - ученні «про розуміння, про осягнення предметів наук о дусі» ${ }^{38}$ підкреслюється вторинний характер інтерпретації, зумовлений завданням роз'яснення й осягнення сутності будь-якого явища. Об'єктами інтерпретації є загалом мова, культура та іï феномени, будь-який факт (науковий, художній), динаміка творчого процесу та результати останнього - твори, усвідомлені як тексти, та їхні окремі параметри. У процесі інтерпретування відбувається поєднання відомого, зрозумілого й інформаційно нового, привнесеного у зміст тексту-оригіналу інтерпретатором. Сенс даного процесу полягає у створенні іншої (іноді вільно трактованої) версії на основі вихідної моделі.

Під час інтерпретації особливого значення набуває функція розуміння, що полягає в «розшифруванні сенсу, який стоїть за

\footnotetext{
${ }^{36}$ Большая советская энциклопедия : в 30-ти т. / гл. ред. А. Прохоров. 3-е изд. Москва : Советская энциклопедия, 1974. Т. 18 : Дикт - Отолиты. С. 214.

37 Коновалова I. Феноменологія музичної обробки (на матеріалі хорових творів українських композиторів XIX-XX ст.) : дис. ... канд. мистецтвозн.: 17.00.01. Харків, 2007. С. 16.

${ }^{38}$ Философский энциклопедический словарь. Москва : Инфра, 2001. С. 99.
} 
очевидним сенсом»39, роз'ясненні знаків тексту та виявленні множинності їхніх смислів, що досягаються через численні тлумачення останнього як певного тексту. Під час розуміння або «інтерпретується «сенс» <..>, або відбувається подальше осмислення того, що вже має деякий зміст» ${ }^{40}$.

Відштовхуючись від початкового образу, інтерпретатор на підставі розуміння образно-змістового ряду оригіналу створює його нову, переосмислену версію, яка $є$ результатом інтерпретації. У свою чергу, оновлений (інтерпретований) первісний образ є початковою моделлю для створення інших версій у наступному колі пізнавального процесу. Завдяки дії інтерпретації, через роз'яснення значення будь-чого, певної даності відбувається основний приріст знання, вилучений із текстів як семіотичних структур, та створюється якісно нове явище, що відрізняється оригінальністю та потенційно художньо-історичною унікальністю.

Інтерпретація, усвідомлена як метод пізнання, є генетичною основою мистецтва - художнього відображення дійсності. У мистецькій діяльності актора, режисера, музиканта і т. п. інтерпретацію пов'язують iз творчим розкриттям «будь-якого художнього твору, що визначається ідейно-художнім задумом та індивідуальними особливостями артиста» ${ }^{41}$. Основою художньої інтерпретації як діяльності і вторинного творчого процесу, який не існує поза первинними креативними діями, є творчість, спрямованість на творення продукту ${ }^{42}$.

Музичне мистецтво, як і мистецтво загалом, у своєму бутті інтерпретаційне. Актуальною та значущою проблема художньої інтерпретації виявляється в контексті музичного мислення, оскільки охоплює галузь розуміння динамічного креативного процесу, результатом якого $\epsilon$ музичні твори, царина музичного інтонування, що охоплює авторські та виконавські аспекти. У свою чергу, твори музичного мистецтва результати первинної творчості, що є проявами авторської свідомості і специфічними узагальненнями процесів композиторського тлумачення картини світу, також відкриті для інтерпретації як вторинної дії.

Згідно із цим механізми художньої інтерпретації, віддзеркалені в іiі різновиді - музичній інтерпретації, властиві різним сферам музичної діяльності й охоплюють композицію, виконавство, музикознавчий аналіз, слухове сприйняття. Специфічною сферою функціонування художньої інтерпретації як процедури С. Гуренко вважає музичну обробку ${ }^{43}$.

\footnotetext{
${ }^{39}$ Рикер П. Конфликт интерпретаций : очерки о герменевтике. Москва : Academia-центр : Медиум, 1995. С. 18.

40 Дильтей В. Описательная психология. Пер. с нем. Санкт-Петербург : Алетейя, 1996. С. 35.

41 Словарь иностранных слов. Москва : Русский язык, 1981. С. 203.

42 Гуренко Е. Проблемы художественной интерпретации : философский анализ. Новосибирск : Наука, 1982. С. 101

43 Гуренко Е. Проблемы художественной интерпретации : философский анализ. Новосибирск : Наука, 1982. С. 103.
} 
У дослідницькому полі традиційним $\epsilon$ погляд на музичну інтерпретацію насамперед як на проблему виконавської творчості сферу інтонаційного тлумачення звукових образів, а також іï перетинів iз композиторською практикою. У контексті даного дослідження, пов'язаного з розглядом обробки в дискурсі музичної авторології, акцентується увага на сутнісних проявах композиторської інтерпретації. Вихідною методологічною позицією означеної скерованості $\epsilon$ запропоноване В. Москаленко визначення інтерпретації видом музичномисленевої діяльності, що відтворює «сутність усякого музичнотворчого процесу <..> «виробництва» музичної думки, де саме відбувається кристалізація «інтонаційного смислу», пізнання музичнохудожньої ідеї» ${ }^{44}$.

Вагомим в цьому сенсі $є$ твердження Ю. Свдокимової, яка вважає, що «інтерпретаційний момент <..> має історичне коріння в композиторській творчості» ${ }^{45}$, а також теза Г. Когана щодо діалектичного зв'язку творчості (як первинної діяльності) та інтерпретації (вторинної діï). Виходячи із власного розуміння творчості як інтерпретації дійсності загалом (у широкому розумінні обробки іiі даних), учений уважає, що «всяка творчість $є$ інтерпретацією та всяка <..> художня інтерпретація - творчість» ${ }^{46}$. Висвітлені теоретичні положення дозволяють зробити висновок про найзначнішу роль у музичній інтерпретації творчості як iii рушійної сили, та зв'язок явищ композиції й інтерпретації.

Об’єктом музичної інтерпретації в загальному плані є образи світу як джерело формування авторської музичної концепції. Інтерпретації підлягають також репрезентанти різних культурних традицій та художніх контекстів - фольклорні та культові наспіви, музичні твори професійної творчості, жанрово-стильові моделі, що використовуються (деякою мірою цитуються й опрацьовуються) композиторами у власній творчості, підпорядковуються авторській художній меті. У цьому сенсі музична інтерпретація актуалізує процес переосмислення мистецької спадщини та художніх традицій загалом ${ }^{47}$.

Першоджерелом музичної інтерпретації $\epsilon$ певний музичний текст індивідуально-авторського або колективно-авторського походження «здатне до відтворення джерело інформації» ${ }^{48}$. Процес музичної інтерпретації відбувається через усебічне осягнення митцем-

\footnotetext{
44 Москаленко В. Творческий аспект музыкальной интерпретации (к проблеме анализа) : исследование. Киев : Киевская государственная консерватория им. П.И. Чайковского, 1994. С. 15.

${ }^{45}$ Евдокимова Ю. Проблемы первоисточника. Советская музыка. 1977. № 3. С. 112

${ }^{46}$ Коган Г. Парадоксы об исполнительстве. О музыке: проблемы анализа. Москва : Советский композитор, 1974. С. 344-345.

47 Коновалова I. Феноменологія музичної обробки (на матеріалі хорових творів українських композиторів XIX-XX ст.) : дис. ... канд. мистецтвозн.: 17.00.01. Харків, 2007. С. 71.

48 Козаренко О. М.В. Лисенко як основоположник української національної музичної мови : автореф. дис. ... канд. мистецтв. Київ : НМАУ, 1993. С. 8. 
інтерпретатором змісту первинного тексту та психологічне вживання в його емоційний підтекст. Основним вектором такого процесу є розкриття прихованих у музичному першоджерелі сенсів шляхом створення його нових художніх версій, оновлення змістовних параметрів.

Зокрема, звернення композиторів до вихідної інтонаційної тези твору як первинної моделі з метою їх творчого розвитку створює особливу діалогічну ситуацію, що зумовлює різноманітне ставлення до оригіналу, сприяє його семантичному переосмисленню. У цій ситуації композитор творчо переінтоновує (у широкому смислі обробляє) музичне першоджерело виходячи 3 власного художнього розуміння та методик композиційного тлумачення цілого, окремих його темброво-фактурних елементів. Унаслідок переосмислення моделі виникає іiї нова авторська версія з відмінними від початкового образу художньо-семантичними, жанрово-стильовими властивостями. За цих умов можна вважати композиторську інтерпретацію особливим творчим процесом / результатом тлумачення, перекладу та композиційного переосмислення музичних творів у нову інтонаційно-семантичну якість ${ }^{49}$.

Креативні аспекти музичної інтерпретації (виконавські, художньопосередницькі та композиторські) $є$ необхідними умовами створення перекладення, транскрипції, обробки, аранжування й ін. жанрів, які фіксують усі стадії інтерпретації як багатогранного пізнавального процесу, здійсненого на принципах діалогу та розуміння. У цьому сенсі музична обробка та ії різновиди є найближчими до художньої (музичної) інтерпретації жанрами в музичному мистецтві. Функціювання вказаних жанрових різновидів як форм інтерпретації музичних текстів в історикокультурній еволюції художнього мислення зумовлені широтою творчих завдань за оновленням первинного образу ${ }^{50}$.

У широкому сенсі обробка постає специфічним віддзеркаленням діалектики об'єктивного та суб'єктивного як обов'язкової умови інтерпретації музичного твору, що регулюється діалоговими відносинами між інтерпретатором - автором обробки, композитором (суб'єктом пізнання) та музичним першоджерелом (об'єктом пізнання). Сенс даного діалогу полягає «в осягненні іманентних властивостей першоджерела через його інтерпретування та тлумачення» ${ }^{51}$.

Об'єктом обробки як форми художньої інтерпретації $є$ музичні тексти - носії певної традиції (усної чи писемної), стилю, культурних пластів, що виокремлюються 3 історико-культурних контекстів як інтонаційно-семантична модель. Процес музичної обробки / опрацю-

\footnotetext{
49 Коновалова I. Феноменологія музичної обробки (на матеріалі хорових творів українських композиторів XIX-XX ст.) : дис. ... канд. мистецтвозн.: 17.00.01. Харків, 2007. С. 71.

${ }^{50}$ Там само. С. 72.

51 Коновалова I. Розуміння як проблема сучасної культурології (на прикладі жанру хорової обробки). Вісник Міжнародного слов'янського університету. Серія «Мистецтвознавство». Харків, 2004. T. VII. № 1. C. 39.
} 
вання здійснюється композитором (суб'єктом), який стає інтерпретатором-виконавцем тексту твору та водночас автором його нової версії, створеної на основі переосмислення образно-семантичної моделі. Суб'єкт-об'єктні співвідношення розкривають міру авторськоінтерпретаторської свободи в оперуванні першоджерелом, можливість привнесення нових образно-семантичних елементів, що результуються в новому музичному творі.

Музична обробка, розглянута як специфічний процес-результат композиції та інтерпретації, містить загальні ознаки механізму творчості, центральною 3 яких є інтуїція - форма безпосереднього знання, що поєднує в собі раціональні й ірраціональні (чуттєві) аспекти. Важливими складовими частинами музично-композиційного процесу $\epsilon$ творчі імпульси та комплекс креативних настанов, критеріїв оцінки і логічних принципів відбору елементів майбутнього твору, а також поле творчого уявлення та фантазія ${ }^{52}$. Зазначене також притаманне художній (музичній) інтерпретації, що здійснюється за умов співвідношення інтелектуального й емоційно-чуттєвого начал шляхом цілісного естетичного уявлення первинного тексту та виокремлення характерних його елементів 3 їх подальшим використанням у композиційному процесі.

Суттєвою передумовою музичної обробки-інтерпретації $\epsilon$ усвідомлення ідеї твору на підставі розуміння сенсу обраної моделі, що виконує функцію зв'язку між першоджерелом та його новими версіями, утвореними композитором у динаміці процесу креації.

Отже, музична обробка повною мірою відповідає характеру мистецтва пояснення, перекладу та $\epsilon$ специфічною формою інтерпретації. Художньо-інтерпретаційні аспекти, властиві обробці, реалізуються в низці споріднених 3 нею різновидів творчості (перекладання, транскрипції, аранжування тощо), щодо яких обробка постає вищим узагальнюючим явищем і усвідомлюється як метажанр.

\section{3. Специфіка культурної екзистенції обробки в музичному мистецтві і системі композиторської творчості}

Специфічним і різнорівневим явищем обробка постає в музичній культурі, виступає особливою сферою творчої реалізації художніх цінностей i трансляцією соціокультурного досвіду, що містить та відтворює виконавські і композиторські аспекти. Значною мірою обробка є показником рівня розвитку мистецтва, «естетичних орієнтирів певної історичної доби, ідеологічних позицій та художніх смаків поколінь» ${ }^{53}$.

\footnotetext{
${ }^{52}$ Муха А. Процесс композиторского творчества (проблемы и пути исследования). Киев : Музична Україна, 1979. С. 195-199.

${ }_{53}$ Коновалова І. Поняття «музична обробка»: до проблеми дефініції. Традиції та новації у вищій архітектурно-художній освіті : збірка наукових праць вузів художньо-будівничого профілю України і Росії ; Харківська державна академія дизайу і мистецтв. Харків : ХДАДМ, 2006. № № 4, 5, 6. С. 115. 
У мистецькій царині музична обробка має множинність значень i проявів. У широкому розумінні музичну обробку можна трактувати як засіб «омузичення» будь-якої художньої ідеї (зокрема поетичної) шляхом акту творення музичної композиції. У вузько-конкретному тлумаченні музична обробка пов'язана із принципами мовного i композиційного оновлення певного тематизму, а також фактурної адаптації музичного першоджерела до інших виконавських умов та $\epsilon$ атрибутом існування музичного твору, його динаміки.

Під музичною обробкою розуміють комплекс мовнохудожніх прийомів розвитку музичного матеріалу, які в аспекті своєї поширеності, стійкості й загальнозначущості стають стиле- та жанротворчими механізмами в музичному мистецтві, становлять ознаку авторського стилю, виявляють особливості індивідуального художнього мислення «духовної, розумової діяльності композитора у процесі творчості» ${ }^{54}$, що $\epsilon$ вагомою часткою єдиної системи музичної діяльності (разом із виконавською співтворчістю та слухацьким сприйняттям). У всіх зазначених аспектах обробка $\epsilon$ проявом іманентних властивостей музики, механізмом продуктивного музично-художнього мислення, засобом його здійснення та специфічним результатом.

У контексті професійного музичного мислення обробка водночас $\epsilon$ найдавнішим методом оновлення тематизму, найтрадиційнішим жанром авторської творчості та конкретним твором. Така множинність екзистенцій феномена та, відповідно, тлумачень поняття «музична обробка» споріднена з розумінням в музикознавчій літературі поняття «музична композиція», що фокусує в семантиці терміна рух від діяльності композитора до іiі результату - музичної форми у вузькому сенсі ${ }^{55}$.

Широкий діапазон художньо-практичної реалізації музичної обробки від опрацювання традиційних (культових і фольклорних) наспівів, трактувань авторських творів як музичної цілісності (транскрипцій, аранжувань) до явища полістилістики (цитування та синтезування конкретних історичних й авторських стилів) демонструє необмежені можливості даної сфери творчості, ії потенційну відкритість та креативну мобільність.

Базисною структурою музичної обробки є певні запозичені музичні тексти (культові, фольклорні й авторські), інтерпретація, творче переінтонування та мовна адаптація яких до інших комунікативножанрових і виконавських умов забезпечують збереження та трансляцію мистецького досвіду, власне культурний розвиток. Згідно із цим музична обробка розуміється нами як «креативна, цілеспрямована індивідуальноавторська аккультурація існуючих, первинно даних музичних текстів» ${ }^{56}$.

\footnotetext{
54 Сохор А. Социальная обусловленность музыкального мышления и восприятия. Проблемы музыкального мышления. Москва : Музыка, 1992. С. 59.

${ }_{55}$ Назайкинский Е. Логика музыкальной композиции. Москва : Музыка, 1982. С. 14.

56 Коновалова I. Феноменологія музичної обробки (на матеріалі хорових творів українських композиторів XIX-XX ст.) : дис. ... канд. мистецтвозн.: 17.00.01. Харків, 2007. С. 82.
} 
На нашу думку, в обробці як культурному явищі знаходять особливе втілення найважливіші для мистецтва принципи і співвідношення: традиції та новаторства, повторності і контрасту, остинатності та перемінності, варіантності (варіаційності) та імпровізаційності ${ }^{57}$. Специфічного відтворення в обробці набувають антиномії «своє чуже», «цитоване - авторське», «суб'єктивне - об'єктивне».

Діалектична взаємодія традиції та новаторства, що віддзеркалює сутність спадкоємності культури, виявляється в музичній обробці, зокрема: 1) у формі збереження, перетворення та трансляції обраних образно-семантичних моделей (фольклорних, культових або авторських текстів); 2) у діалогічному характері творчості та співтворчості, що висвітлюється за умов інтерпретації авторами обробок музичної спадщини певних історичних епох, національних традицій, художніх систем; 3) у переосмисленні першоджерела та його перепідпорядкуванні новій індивідуально-авторській художній меті в межах певного стилю, жанру.

Дія принципів варіантності та варіаційності в парадигмі обробки пов'язана 3 розумінням первинного музичного матеріалу як певного тематизму, проте опрацювання - як процесу варіювання інтонаційносемантичного першоджерела, створення на його основі версій варіантів оригіналу.

Активно проявляється в музичній обробці як формі діяльної авторепрезентації композитора принцип імпровізаційності, що засвідчує можливість використання митцем непередбачених, випадкових елементів в осмисленні першоджерела та вільного процесуального розгортання музичної думки, а також спорідненість із фольклорним музикуванням та художніми техніками комбінування «готових» елементів (алеаторика, джаз), обов'язковою умовою для яких $\epsilon$ відношення «тотожність - варіантне оновлення».

Особливо значуще в музичному мистецтві функціювання обробки / опрацювання як творчого методу, що трактується як «складний процес перекодування творчою свідомістю реальності, що безперервно пізнається, у художнє явище» ${ }^{58}$, а також «засіб досягнення певної мети, сукупність прийомів або операцій практичного освоєння дійсності» ${ }^{59}$.

Розглянута як сфера авторепрезентації і метод музичної діяльності, що віддзеркалює характер співвідношення об'єктивних та суб'єктивних моментів, взаємодією раціонального й емоційного, нормативного та

\footnotetext{
${ }^{57}$ Коновалова И. Жанр обработки как явление художественной интерпретации в музыке. Традиції та новації у вищій архітектурно-художній освіті : збірка наукових праць вузів художньо-будівничого профілю України і Росії ; Харківська державна академія дизайну і мистецв. Харків : ХДАДМ, 2003/2004. № № 5-6, 3-4. C. 50 .

${ }^{58}$ Горюхіна Н. Постановка проблеми творчого методу в теоретичному музикознавстві. Украйнське музикознавство : республіканський міжвідомчий науково-методичний збірник. Київ : Музична Україна, 1980. Вип. 15. С. 14.

${ }_{59}$ Философский энциклопедический словарь. Москва : Инфра, 2001. С. 266. 
ненормативного, узагальнюючого й емпіричного, абстрактного та конкретного $^{60}$, обробка постає «засобом самоорганізації у процесі творчості та комплексом конкретних прийомів реалізації художньої авторської ідеї» ${ }^{61}$. Даний метод презентує систему інтелектуальних позицій та індивідуальних творчих настанов композитора, розмаїття індивідуально використаних i творчо застосованих митцем мовнокомпозиційних ресурсів.

У царині музичного мистецтва поряд 3 обробкою існує й інший, антиномічний попередньому за творчим вектором метод - розробки, сенс якого полягає в радикальній трансформації музичного матеріалу, певної мелодії шляхом порушення ऑii первинної цілісності через дроблення на окремі мотиви (з наданням останнім конструктивної самостійності), активне образно-смислове та композиційне перетворення первинних змістовних параметрів ${ }^{62}$.

А. Сохор звертає увагу на специфіку обробки та розробки як різних, але взаємопов'язаних методів, на прикладі перетворення народнопісенних мелодій у професійній музиці, ознаками методу обробки називає достовірне використання композитором в повному обсязі наспіву і словесного тексту пісні (з підкресленням їі змісту та мовної своєрідності). Утім, для методу розробки, симфонізації пісенного мелосу дослідник уважає основним суб'єктивно-особистісне начало, ініціативно-авторське ставлення до моделі, що віддзеркалюється в частковому використанні пісенного наспіву, наданні йому під час розвитку нових сенсів ${ }^{63}$.

Основою методу обробки / опрацювання як специфічного щодо фольклорних і культових інтонаційних джерел та відмінного від розробки (своєю помірністю в тактиці оновлення), є варіювання запозиченої мелодії як носія інтонаційно-образного змісту. Зазначені принципи сприяли ототожненню обробки 3 методом художнього цитування в музиці.

В. Москаленко вважає виражальні аспекти художнього цитування (зокрема, фольклорного мелосу в симфонічній музиці) лабораторією варіантно-варіаційних методів розвитку та підставою для еволюції жанру варіацій ${ }^{64}$. Функцію методу цитування вчений вбачає у взаємозв'язку об'єктивної виразності народного джерела i його смислової ролі в умовах конкретного твору та відзначає сутнісною

\footnotetext{
${ }^{60}$ Сохор А. Эстетическая природа жанра в музыке. Вопросы социологии и эстетики музыки. II. Статьи и исследования. Ленинград : Советский композитор, 1981. С. 49.

${ }^{61}$ Соколов А. К проблеме типологии музыкальных жанров. Проблемы музыки ХХ в. Горький : Волговятское книжное изд-во, 1977. С. 30.

${ }_{62}$ Музыкальная энциклопедия : в 6-ти т. Москва : Советская энциклопедия, 1978. Т. 4. С. 522.

${ }^{63}$ Сохор А. Традиции и новации в творчестве Свиридова. Вопросы сощиологии и эстетики музыки. III. Статьи и исследования. Ленинград : Советский композитор, 1983. С. 274

64 Москаленко В. Про виражальну функцію цитування народних мелодій у сучасноному симфонізмі / В. Москаленко. Сучасна музика. Київ : Музична Україна, 1973. Вип. 1. С. 27-28.
} 
рисою безпосередність вислову фольклорної думки та іiі творче осмислення без «цілковитого розпаду об'єктивно закріпленого за даною мелодією рівня образно-семантичної конкретності» ${ }^{65}$.

На нашу думку, обробка та розробка - семантично значущі методи музичного розвитку, що ілюструють різні рівні творчого впливу на базовий інтонаційний матеріал, у широкому розумінні постають культуротворчими механізмами в музичному мистецтві, підставою стиле- та жанротворення. Властива обробці здатність до модернізації і творчого переосмислення (переінтонування) музичних джерел зумовлена характером авторського ставлення до художнього явища як об'єкта пізнання та скерованістю на відкриття нового в тому, що вже існує.

Специфічне переломлення методи музичної обробки/опрацювання дістають стосовно кількісно-якісних видозмін конкретних творів як вихідного музичного тексту, утворюють низку споріднених за природою жанрів музичного мистецтва, об'єднаних у специфічну систему «вторинного» авторського тлумачення першоджерел. Різновиди цієї системи (перекладення, транскрипція, аранжування, обробка, редакція, фантазія, пародія, парафраза тощо), на наш погляд, фокусують у собі різні композиційно-семантичні рівні обробки як жанру i методу музичного розвитку та базуються на принципах інтерпретації. Підставою для диференціації цих жанрів та їхньої назви стає регламентація креативно-інтерпретаційних дій у широкому діапазоні від незначного мовно-контекстового пристосування моделі до нових фактурно-виконавських умов до кардинального образно-семантичного та структурно-композиційного перетворення вихідної тези.

Варто зазначити, що в бутті музичної культури обробка, що має множинний прояв як специфічний творчий результат, зазнає амбівалентного тлумачення i трактується, 3 одного боку, як узагальнюючий вид музичної творчості в системі вищезазначених художніх явищ (транскрипція, перекладання тощо); 3 іншого - як самостійний музичний жанр, що застосовується в різних виконавських сферах (вокально-хорова, інструментальна), функціонує в численних жанрово-стильових контекстах (фольклорна, культова, джазова обробка) та індивідуально-авторських експікаціях.

У зв'язку з вищезазначеним жанр обробки розглядається як особливий художній результат культуротворчого процесу обробки, що вбирає i фіксує в конкретних творах комплекс принципів музичного опрацювання. Обробка як жанр є формою композиторського тлумачення й образно-семантичного переосмислення цитованих музичних текстів (авторських або анонімних) як художньо-інформаційних об’єктів із метою створення на їх основі нової художньої цілісності.

${ }^{65}$ Там само. С. 43-44. 
Особливої значущості для становлення $\mathrm{i}$ розвитку музичного мистецтва, сфери музичного авторства й індивідуальних композиторських стилів набуває жанр у парадигмальній системі обробки, конкретизований у назвах «хоральна обробка», «обробка знаменного розспіву», а також «обробка народної пісні», що ототожнюється 3 композиторською рецепцією етнотрадиційної музичної спадщини, $\epsilon$ художнім утіленням автентичного інтонаційного першоджерела, перенесеного з фольклорного середовища і трансплантованого в царину професійної творчості 3 новими мовними характеристиками. Означений жанр є динамічним чинником збереження і розвитку мистецьких, зокрема національних, традицій, віддзеркалює рівень розвитку виконавської і композиторської творчості, художні смаки слухацької аудиторії та сприяє «розширенню культурного контексту художніх ідей» ${ }^{66}$.

\section{ВИСНОВКИ}

Музична обробка - одне 3 найзначніших явищ у системі музичної культури і парадигмі художньої творчості, що виражає саму сутність креативної діяльності композитора, та постає формою об’єктивації авторської свідомості. У музичній обробці акумулюється комплекс інтелектуально-художніх та інтерпретаційно-перекладацьких дій, а також композиційних прийомів, методів та принципів роботи 3 музичним матеріалом, які (згідно з історико-культурним контекстом) визначають характер та спрямованість музичної творчості.

Багатогранність і широта смислових проявів музичної обробки (від концептуальних жанрово-стильових до локальних музичнотехнологічних аспектів), множинність мистецької екзистенції як сфери авторепрезентації і композиторської інтерпретації, методу і жанру засвідчують універсальність ії властивостей як музичного феномену і форми культури.

Обробка, будучи різновидом композиторської типізації, демонструє спрямованість на вияв нового в уже створеному й існує в контексті вирішення найактуальніших для сучасної культури проблем - авторства, інтерпретації, діалогу. Функціювання музичної обробки як особливої царини культурних інновацій та мистецької спадкоємності становить важливу частку культурно-історичного процесу.

У музичній культурі феномен обробки історично пов'язаний із жанровим віддзеркаленням результату розуміння, художнього тлумачення та засвоєння - переосмислення субстрату національної духовності, здійсненням міжкультурної творчої взаємодії різних пластів і мовних систем (фольклорна та професійна).

\footnotetext{
${ }^{66}$ Арановский М. Структура музыкального жанра и современная ситуация в музыке. Музыкальный современник : сборник статей. Москва : Советский композитор, 1987. Вып. 6. С. 8.
} 
На основі амбівалентного тлумачення музичної обробки як методу та жанру, що співвідносяться один з одним відповідно до пропонованих векторів трактування обробки (як процесу та результату), пропонуємо таке визначення. Музична обробка - культуротворчий процес змістовнокомпозиційного переосмислення та перетворення існуючих текстів музичної культури - традиційно-канонічних і авторських - та водночас результат цього процесу - формування нового художнього синтезу авторського твору як вторинної інтонаційно-семантичної цілісності із власними соціально-комунікативними, жанрово-стильовими та фактурно-композиційними властивостями.

\section{АНОТАЦІЯ}

Дослідження присвячене висвітленню семантичної специфіки музичної обробки як мистецького явища, сфери композиторської авторепрезентації та різновиду художньої інтерпретації. Розкрито культуротворчу сутність і амбівалентність естетико-смислових проявів музичної обробки як процесу і результату музичної діяльності, методу розвитку і мистецького жанру.

Виявлено широту поширення і багатогранність мистецької екзистенції музичної обробки (від концептуальних жанрово-стильових до локальних музично-технологічних аспектів), що засвідчують універсальність іiі властивостей як музичного феномену і форми культури. Доведено, що функціювання музичної обробки як особливої царини художніх інновацій та мистецької спадкоємності становить важливу частку культурно-історичного процесу.

\section{ЛІТЕРАТУРА}

1. Арановский М. Структура музыкального жанра и современная ситуация в музыке. Музыкальный современник : сборник статей. Москва : Советский композитор, 1987. Вып. 6. С. 5-44.

2. Бахтин М. Эстетика словесного творчества. Москва, 1979. 424 с.

3. Большой российский энциклопедический словарь. Москва : БРЭ, 2003. 1888 c.

4. Большая советская энциклопедия : в 30-ти т. / гл. ред. А. Прохоров. 3-е изд. Москва : Советская энциклопедия, 1974. Т. 18 : Дикт - Отолиты. $632 \mathrm{c.}$

5. Борисенко М. Жанр транскрипції в системі індивідуального композиторського стилю : автореф. дис. ... канд. мистецтв. Харківський державний університет мистецтв ім. І.П. Котляревського. Харків : ХДУМ, 2005. 17 с.

6. Великий тлумачний словник сучасної української мови / уклад. і ред. В. Бусел. Київ ; Ірпінь : ВТФ «Перун», 2001. 1440 с. 
7. Гаврюшенко О., Шейко В., Тишевська Л. Історія культури : навчальний посібник. Київ : Кондор, 2004. 763 с.

8. Гливинский В. Жанр обработки в позднем творчестве И. Стравинского. Позднее творчество И.Ф. Стравинского : исследование. Донецк : Донеччина, 1995. С. 159-175.

9. Годовский Л. По поводу транскрипций, обработок и парафраз. Транскрипиии для фортепиано : в 2 руки. Песни Ф. Шуберта / сост. К. Сорокин. Москва : Музыка, 1970. Вып 1. С. 41-49.

10. Голомб М. Транскрипції музичних творів у XIX ст. Спроба типології на прикладі творів Фрідеріка Шопена (переклад з польської М. Кушніра). Фридерік Шопен : збірник статей. Львів : Сполом, 2000. C. 201-222.

11. Горюхіна Н. Постановка проблеми творчого методу в теоретичному музикознавстві. Українське музикознавство : республіканський міжвідомчий науково-методичний збірник. Київ : Музична Україна, 1980. Вип. 15. С. 14-21.

12. Гуренко Е. Проблемы художественной интерпретации. Философский анализ. Новосибирск : Наука, 1982. 256 с.

13. Дильтей В. Описательная психология. Санкт-Петербург : Алетейя, 1996. $155 \mathrm{c.}$

14. Давидов М. Про музично-естетичний зміст творчого процесу перекладання музичних творів для баяна. Украӥнське музикознавство. Київ, 1974. Вип. 10. С. 200-207.

15. Дейнега В. Оркестровка як різновид інтерпретації. Науковий вісник Начіональної музичної академії ім. П.І. Чайковського : збірник статей. Київ : НМАУ, 2001. Вип. 18. С. 133-142.

16. Демченко А. Жанр фольклорной обработки в музыкальном искусстве России начала XX в. Развитие народных традищий в музыкальном исполнительстве, творчестве и педагогике : опыт коллективного исследования : межвузовский сборник научных трудов / ред.-сост. Д. Варламов. Екатеринбург : Уралтрейд, 2000. С. 35-41.

17. Евдокимова Ю. Органные хоральные обработки Баха. Русская книга о Бахе : сборник статей / сост. Т. Ливанова, В. Протопопов. Москва : Музыка, 1985. С. 221-247.

18. Евдокимова Ю. Проблемы первоисточника. Советская музыка. 1977. № 3. С. 109-112.

19. Жарков О. Художній переклад в музиці: проблеми і рішення : автореф. дис... канд. мистецтв. Київська державна консерваторія ім. П.І. Чайковського. Київ : КДК, 1994. 27 с.

20. Иванова Л. Жанр фольклорной обработки в русской музыке XX в. Развитие народных традиций в музыкальном исполнительстве, творчестве и педагогике : опыт коллективного исследования : 
межвузовский сборник научных трудов / ред.-сост. Д. Варламов. Екатеринбург : Уралтрейд, 2001. С. 66-71.

21. Коган Г. Парадоксы об исполнительстве. О музыке : проблемы анализа. Москва : Советский композитор, 1974. С. 344-365.

22. Козаренко О. М.В. Лисенко як основоположник української національної музичної мови : автореф. дис. ... канд. мистецтв. Київська національна музична академія України. Київ : НМАУ, 1993. 29 с.

23. Коновалова И. Жанр обработки как явление художественной интерпретации в музыке. Традищії та новації у вищій архітектурнохудожній освіті : збірник наукових праць вузів художньо-будівельного профілю України і Росії. Харківська державна академія дизайну і мистецв. Харків : ХДАДМ, 2003/2004. № № 5-6, 3-4. С. 48-51.

24. Коновалова І. Поняття «музична обробка»: до проблеми дефініції. Традииії та новації у вищій архітектурно-художній освіті : збірник наукових праць вузів художньо-будівельного профілю України і Росії. Харківська державна академія дизайу і мистецтв. Харків : ХДАДМ, 2006. № № 4, 5, 6. С. 112-116.

25. Коновалова I. Розуміння як проблема сучасної культурології (на прикладі жанру хорової обробки). Вісник Міжнародного слов'янського університету. Серія «Мистецтвознавство». Харків : Вісник МСУ, 2004. T. VII. № 1. C. 38-42.

26. Коновалова I. Феномен композитора в часопросторі європейської музичної культури ХХ століття: модуси теоретичного осягнення : монографія. Харків : ТОВ «Планета-Принт», 2018. 480 с.

27. Коновалова I. Феноменологія музичної обробки (на матеріалі хорових творів українських композиторів XIX-XX ст.) : дис. ... канд. мистецтвозн.: 17.00.01. Харків, 2007. 226 с.

28. Культурология в вопросах и ответах / под ред. Г. Драча. Москва : Гардарики, 1999. 336 с.

29. Липс Ф. О переложениях и транскрипциях. Баян и баянисты. Москва : Советский композитор, 1977. Вып. 3. С. 86-108.

30. Матусевич Н. Гармонічне варіювання в обробках українських народних пісень М. Лисенка. Українське музикознавство : збірник наукових праць. Київ, 1957. Вип. 2. С. 81-90.

31. Москаленко В. Про виражальну функцію цитування народних мелодій у сучасноному симфонізмі. Сучасна музика. Київ : Музична Україна, 1973. Вип. 1. С. 25-59.

32. Москаленко В. Творческий аспект музыкальной интерпретации (к проблеме анализа) : исследование. Киев : Киевская государственная консерватория им. П.И. Чайковского, 1994. 157 с. 
33. Микенайте P. Особенности гармонического языка обработок литовских народных песен. Вопросы теории музыки. Москва : Музыка, 1975. Вып. 3. С. 213-236.

34. Музыкальная энциклопедия : в 6-ти т. Москва : Сов. Энциклопедия, 1976. Т. 3. $1102 \mathrm{c.}$

35. Музыкальная энциклопедия : в 6-ти т. Москва : Советская энциклопедия, 1978. Т. 4.974 с.

36. Музыкальный энциклопедический словарь / отв. ред. Г. Келдыш. Москва : Большая советская энциклопедия, 1959. 324 с.

37. Муха А. Процесс композиторского творчества (проблемы и пути исследования. Киев : Музична Україна, 1979. 269 с.

38. Назайкинский Е. Логика музыкальной композиции. Москва : Музыка, 1982. 319 с.

39. Обработка символьной информации: сборник статей / под ред. В. Серебрякова. Москва : ВЦ АН СССР, 1986. 110 с.

40. Ожегов С., Шведова Н. Толковый словарь русского языка : 80000 слов и фразеологических выражений. Российская академия наук. Институт русского языка им. В. Виноградова. Москва : Азбуковик, 1999. $944 \mathrm{c.}$

41. Прокина Н. Фортепианная транскрипция. Проблемы теории и истории жанра : автореф. дис. ... канд. искусств. Московская государственная консерватория. Москва : МГК, 1988. $21 \mathrm{c.}$

42. Рикер П. Конфликт интерпретаций : очерки о герменевтике. Москва : Academia-центр: Медиум, 1995. 415 с.

43. Руденко В. Концертная скрипичная транскрипция XX века и проблемы интерпретации. Музыкальное исполнительство : сборник статей / сост. и ред. В. Григорьева, В. Натансона. Москва : Музыка, 1979. Вып. 10. С. 22-56.

44. Рязанова Н. Органные хоральные обработки И.С. Баха (их композиционно-структурные особенности) : автореф. дис. ... канд. искусств. Ленинград : ЛГК, 1979. 20 с.

45. Самарин В. Хороведение и хоровая аранжировка : пособие для студентов высших учебных заведений. Москва : Академия, 2002. 352 с.

46. Словарь иностранных слов. Москва : Русский язык, 1981. 624 с.

47. Словник української мови. Київ : Наукова думка, 1974. Т. 5.840 с.

48. Словник української мови : в 11-ти т. / АН УРСР. Інститут мовознавства ; за ред. І. Білодіда. Київ : Наукова думка, 1970-1980. Т. 5. 1974. C. $568-727$.

49. Соколов А. К проблеме типологии музыкальных жанров. Проблемы музыки XX века. Горький : Волговятское книжное изд-во, 1977. C. 4-32. 
50. Сохор А. Социальная обусловленность музыкального мышления и восприятия. Проблемы музыкального мышлления. Москва : Музыка, 1992. C. $59-74$.

51. Сохор А. Традиции и новации в творчестве Свиридова. Bonpocы соииологии и эстетики музыки. III. Статьи и исследования. Ленинград : Советский композитор, 1983. С. 262-302.

52. Сохор А. Эстетическая природа жанра в музыке. Bonpocbl соииологии и эстетики музики. II. Статьи и исследования. Ленинград : Советский композитор, 1981. С. 231-293.

53. Фільц Б. Хорові обробки українських пісень. Київ : Музична Україна, 1965. 133 с.

54. Философский энциклопедический словарь. Москва : Инфра, 2001. $576 \mathrm{c}$.

\section{Information about author:} Konovalova I. Yu.,

Doctor of Art Criticism (Hab. Dr), Associate Professor, Associate Professor at the Department of Theory and History of Music

Kharkiv State Academy of Culture 4, Bursatski Uzviz, Kharkiv, 61057, Ukraine 